\title{
Integrated Water Resource Management in New Zealand: Legislative Framework and Implementation
}

\author{
Matthew D. Davis ${ }^{1}$ and John Threlfall ${ }^{2}$ \\ ${ }^{1}$ CAL Engineering Management and ${ }^{2}$ Otago Regional Council
}

A brief overview of Integrated Water Resources Management (IWRM) in New Zealand is presented, covering the legislative framework and implementation. Two examples are discussed: wet weather quality management in the Auckland Region and water allocation in the Otago Region (Figure 1). It will be shown that a strong legislative framework and territorial organization exist in New Zealand to facilitate IWRM. Translating the framework into actions that support multiple objective IWRM goals remains the current challenge.

IWRM is a process or means to achieve sustainable water use and sustainable water resource systems. Sustainable water use and sustainable water resource systems support social objectives into the indefinite future without undermining hydrologic and ecological integrity (Gleick et al. 1995; American Society of Civil Engineers and United Nations Educational, Scientific, and Cultural Organization 1998). IWRM is best achieved at the river basin or catchment scale - that is at scales comprised of hydrologic drainage basins or subbasins. Cases exist where IWRM can extend beyond hydrologic drainage basin boundaries to what can be defined as problemsheds, in particular when addressing habitat protection. IWRM can also address subsets of basins, particularly when the spatial extent of a catchment or basin is large.

Implementation of IWRM can take many forms, although there are general pathways it often follows (Lee 1999, Molle 2003). In well functioning systems, IWRM is made of policies with clear objectives that in turn are

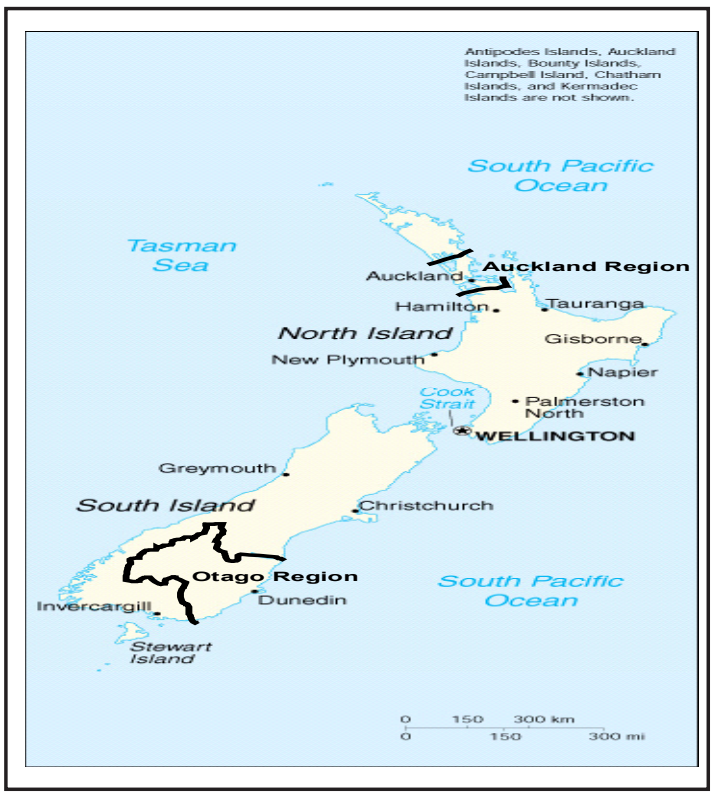

Figure 1. New Zealand and Auckland and Otago Regions.

implemented, monitored, and adapted. IWRM, thus, is comprised of both strategic and operational planning approaches and actions (Mitchell 1990).

\section{Integrated Water Resources Management}

The concept of IWRM has regained prominence in recent years through the Global Water Partnership, World Water Council, multi-lateral lending institutions, and other prominent international fora, including the World Sustainability Summits. These efforts are primarily focused on lessdeveloped countries to address primary issues of poverty reduction and sustainable development criteria, as discussed in Johannesburg in 2002 and incorporated into the "Millennium Development 
Goals." In less-developed countries, IWRM also is associated with coordinating water resource development in river basins (Guerquin et al. 2003).

While sharing many basic tenants, IWRM in developed countries often is motivated by other issues and sometimes not recognized or termed as IWRM. Particular differences are that the poverty reduction and provision of basic water and sanitation services generally have been dealt with in developed countries. At least three patterns emerge for IWRM in developed countries. A first pattern is the creation of river basin organizations or water infrastructure related organizations to develop water resources for economic growth. Examples are the Tennessee River Valley Authority in the United States and the Murray-Darling Basin Commission in Australia. A second pattern is that particular issues, often with an environmental focus, instigate actions that require some form of IWRM, although in many respects these reflect subcomponents of IWRM. Issues include improving ambient river water quality, restoring river habitat, or reconciling competing water uses. Last, another pattern is that in a limited number of countries or regions, water and other regulatory governance institutions have been re-organized around natural catchment boundaries. This activity has occurred in France and New Zealand, for example.

IWRM is in fact an old concept that has re-taken prominence recently. It has progressed actively in some countries since the early 1900s in different forms and under various titles including river basin development, water resource master planning and catchment management. Historically, however, it has proven difficult to achieve and/or sustain - either locally or universally (White 1998, Biswas 2004). Nonetheless, due to its promise and growing competition and stress on water resources, it remains a principal concept to embrace when seeking to achieve improved water and land management - thus leading to a recent re-focus in international circles.

\section{Background}

New Zealand is comprised of three main islands of 268,680 square kilometers, with a population of just over 4 million people. It has a purchasing power parity per capita gross national product of
$\$ 17,500$ (Auckland Regional Council et al. 2006). The climate is temperate, subtropical. Rainfall differs dramatically across the country from more than $13,000 \mathrm{~mm}$ on the west side of the Southern Alps to less than $400 \mathrm{~mm}$ in the rain shadow of the Southern Alps (Kirkpatrick 1999).

IWRM and river basin management in New Zealand were initiated to address early erosion and flood control problems in the newly colonized lands. The country began to organize around river basins as early as 1868 with establishment of river boards. The erosion and flood problems of the 1930s led to the 1941 Soils and Rivers Control Act, one of the first pieces of legislation in the world to link land and water resources. The intensity of land use and continuing soil erosion problems led to a broadening of the scope of existing legislation and promulgation of the 1967 Water and Soils Act. The Act promoted a national policy for water, soil conservation, flood alleviation, community water supply needs, and ecosystem protection. Further, it introduced water quality as a water management objective and established 20 catchment boards. In 1981 the Act was amended, adding provisions for Water Conservation Orders to protect "outstanding" areas of nationally or locally important water bodies. Twenty-one Water Conservation Order applications have been submitted, with 11 areas conferred to date (Newson 1997, Deans 2004a).

In October 1991, the Resource Management Act became governing legislation for the majority of resource use. The Resource Management Act repealed over 60 acts and amended more than 150 others; it transformed a legal mosaic into a more integrated regime for air, land, water, and ecosystem management (Randerson 1997, Harris 2004, Government of New Zealand 2005). The Resource Management Act, together with the 1987 Conservation Act, the 2002 Local Government Act (which revamped an earlier Act of 1974), the 1841 Treaty of Waitangi, and the restructuring of regional and local councils that occurred in the 1980s, constitute a strong foundation for IWRM, based on sustainable water use and sustainable water resource systems principles. Implementation however, largely occurs at the regional and local council levels. 


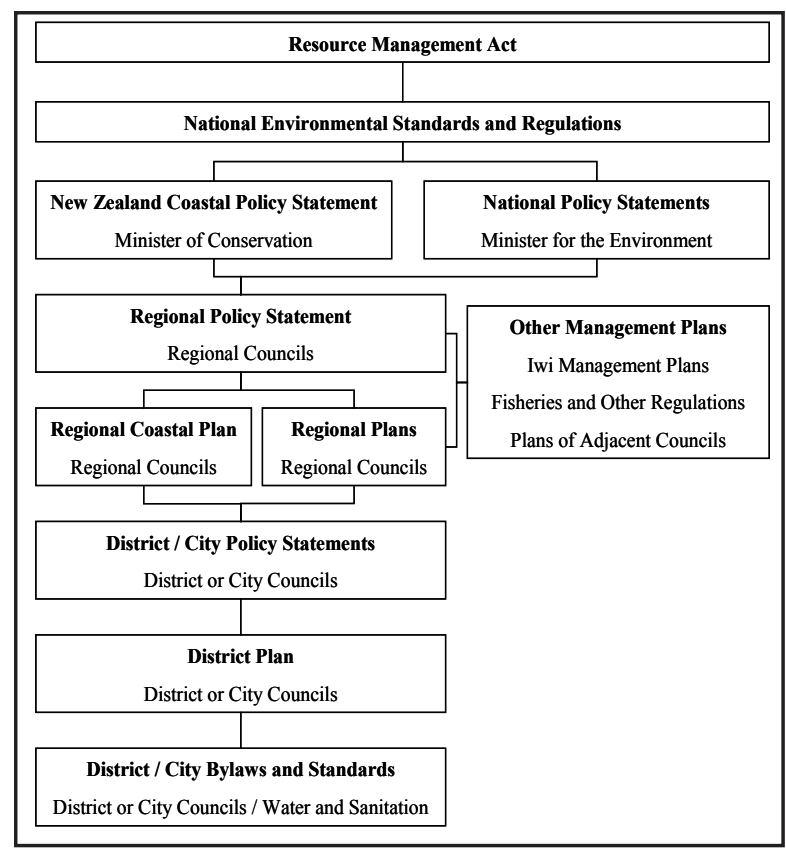

Figure 2. Resource management document hierarchy. Source: Ministry for the Environment 2001, modified.

\section{Regulatory Framework}

In legal, economic, and social terms, water is regarded as a public good in New Zealand. Regional councils, that is government that is comprised of the territory governed by several local councils, administer most aspects of freshwater, while local councils in turn are primarily involved in regulating local land use decisions. Furthermore, regional councils retain regulatory provisions over regional land use. No entity may take, use, dam, divert, or discharge to any water (or heat or energy from water, or heat or energy from material surrounding geothermal water) unless expressly allowed by a rule in a regional plan, granted in a resource consent or falling within a limited number of exemptions. Rights to take, use, dam, divert, or discharge have fixed terms, while at the same time existing use rights, some of which are significant and for extended periods of time are recognized. The English Common Law approach to water was abandoned with the 1967 Water and Soils Act in place of administrative control, reinforced in the 1991 Resource Management Act (Berry and Cowper 1997, Deans 2004a). Primary legislation with respect to water and IWRM are the 1991 Resource Management Act, 1987 Conservation Act, 2002 Local Government Act, and 1841 Treaty of Waitangi.

Together, these acts and re-organization of regional and local councils produced: (a) wholesale privatization of the country's resource base and infrastructure, (b) redrawing of the internal political map using catchment boundaries as the primary organizing principle, (c) amalgamating local councils, and (d) explicitly adopting sustainability as the dominant national policy for renewable natural resource management (Burton and Cocklin 1996). At the same time efforts were renewed to reconcile European and Maori (preEuropean) cultures and Maori resource claims and environmental values (Orange 1987, Ward 1999, Government of New Zealand 2004, 2005).

\section{Resource Management Act}

In October 1991, the Resource Management Act became the governing legislation for nearly all resource use in New Zealand. The purpose of the Resource Management Act is "...to promote the sustainable management of natural and physical resources" (Government of New Zealand 2005: 38). Within the context of the Resource Management Act, the environment is defined as encompassing

...ecosystems and their constituent parts, including: (a) people and communities, (b) all natural and physical resources, (c) amenity values and (d) the social, economic, aesthetic and cultural conditions which affect the matters stated or which are affected by these matters...

(Government of New Zealand 2005: 19).

The Resource Management Act is effects-based legislation that provides a framework for management and mitigation of adverse environmental impacts of activities. The Resource Management Act proposes that "sustainable management" be achieved through explicit management of the effects of activities of local and regional councils and private entities. The Resource Management Act sets the framework for the control of air, land, and water based on a hierarchy of documents, including: (1) policies, (2) plans, and (3) resource consents (Figure 2).

The Resource Management Act co-opted most of the 1967 Water and Soils Act and its 1981 amendment. It sets out five matters of national importance regarding water: (1) preservation of the natural character of the coastal environment, 
Table 1. Activities and consents.

\begin{tabular}{ll}
\hline Activity & \multicolumn{1}{c}{ Definition } \\
Permitted & $\begin{array}{l}\text { No consent is required if the effects comply with the conditions specified in the planning docu- } \\
\text { ments. A certificate of compliance can be issued by the relevant authority to verify this status }\end{array}$ \\
Gontrolled & $\begin{array}{l}\text { Generally a non-notified application. } \\
\text { Consent must be granted, but conditions can be imposed } \\
\text { Giscretionary }\end{array}$ \\
Generally a notified application. \\
Consent may or may not be granted, depending on criteria specified in the planning document. \\
contravenes plan, but not a prohibited activity. \\
Notified application \\
Consent may be granted or refused. \\
Consent cannot be granted in any circumstances. \\
No application permitted. \\
Need a change to the controls to proceed
\end{tabular}

Sources: Randerson 1997, Harris 2004, Government of New Zealand 2005.

wetlands, lakes, and rivers and their margins, (2) protection of these areas from inappropriate subdivision, use, and development, (3) protection of outstanding natural features, areas of significant indigenous vegetation and significant habitats of indigenous fauna, (4) maintenance and enhancement of public access to the coastal marine area, lakes and rivers, and (5) maintenance and enhancement of the relationship of Maori and their cultural traditions with their ancestral lands, water, sites, waahi tapu (sacred sites) and other taonga (treasures) (Government of New Zealand 2005). The 2004 Resource Management Act Amendment also places protection of biodiversity as a matter of national importance (Government of New Zealand 2005).

\section{Activities and Consents}

A regional policy statement, regional plan, or district plan may include control mechanisms that prohibit, regulate, or allow activities. The control mechanisms are based on the actual or potential adverse environmental effects of an activity. Activities may be categorized as permitted, controlled, discretionary, non-complying, or prohibited (Table 1) (Randerson 1997, Harris 2004, Government of New Zealand 2005).

Water Conservation Orders are further subdivided into Preservation Orders and Protection Orders. Preservation Orders are more restrictive and require leaving water in its natural state: no water, coastal or discharge permit may be granted that would alter the water body. Protection Orders allow activities provided that they allow for protection of the specified "outstanding resource" (Deans 2004b, Government of New Zealand 2005).

\section{National Water Policy}

Water allocation and management are recognized as issues of regional and national importance. Nationally, recognizing an absence of national guidance, the Ministry for the Environment initiated a review of water issues as part of its "Sustainable Water Program of Action." Thirteen actions were identified in 2004 (Table 2) (Ministry for the Environment 2004). In 2005, the Ministry for the Environment together with the Minister of Agriculture and Forestry issued a joint statement on water, including investigation of water transfers to encourage increased water use productivity (Ministry for the Environment 2006). A water policy statement on water allocation is expected in the first half of 2007. The statement is not legally binding but will provide guidance. Regional plans consistent with national legislation contain regulations that must be followed.

\section{Implementation of IWRM}

Consequently, implementation of IWRM is largely controlled through national and regional policy statements and rules spelled out in regional and district plans. The country is divided into 12 regional councils plus five unitary councils that serve both as local and regional government bodies. Each of the 12 regional councils is comprised of 
Table 2. Thirteen Actions for freshwater for a sustainable future in New Zealand.

\begin{tabular}{ll}
\hline No. & Actions \\
\hline 1. & Develop national policy statements. \\
2. & Develop national environmental standards. \\
3. & Address important national values. \\
4. & Increase central government participation in regional planning. \\
5. & Increase central government support for local government. \\
6. & Develop special mechanisms for regional councils. \\
7. & Enhance the transfer of allocated water between users. \\
8. & Develop market mechanisms to manage diffuse discharges. \\
9. & Set requirements for regional freshwater plans to address key issues and challenges. \\
10. & Enhance Maori participation. \\
11. & Enable regional councils to allocate water to priority uses. \\
12. & Raise awareness of freshwater problems and pressures, and promote solutions. \\
13. & Collaborate between central and local government, scientists, and key stakeholders on pilot projects to \\
\hline
\end{tabular}

Source: Ministry for the Environment 2004.

several local councils.

Regional councils can prepare single issue plans (e.g. water) or multiple issue plans such as air, land, and water. Some regional water plans, for instance, differ substantially across the country, in part due to recognition of different local conditions but also due to lack of guidance through national water policy statements, resulting in mixed and at times inconsistent rules across regional councils.

The Auckland Regional Council recently promulgated the Regional Plan: Air, Land and Water (Auckland Regional Council 2005), while the Otago Regional Council maintains a Regional Plan: Water for Otago (Otago Regional Council 2004b, 2006b). The case study of the Auckland Region portrays how the regional council is attempting to manage wet weather discharges to the Waitemata Harbor from several district councils through its consenting process governed by the Air, Land and Water Plan. The example from the Otago Region discusses how IWRM concepts are implemented under the Water Plan in the case of regulation and management of water allocation and stream flow.

\section{Conservation Act}

The Department of Conservation holds responsibility to manage freshwater fish, except for commercial fisheries and sports fisheries. The department also manages land adjacent to rivers and lakes, as well as upper catchments for water quality. This last item reflects adoption of the historical role of the original Forest Service that in 1919 was charged with protecting water and soil by protecting forested catchments (Deans 2004a).

Among other functions, the Conservation Act provides the Department of Conservation with the ability to review private resource consent applications on private land that may affect water quality, in particular with regards to when a conservation marginal strip lies between a property to be developed and a water body. In addition, a range of provisions in the Conservation Act and subsidiary regulations provide the Department of Conservation with functions to protect freshwater resources, including regulations for freshwater fisheries (including fish passage and protection of particular species), game management, and provisions for a variety of protected areas (Deans 2004a).

\section{Local Government Act}

Local government's roles, responsibilities, powers and accountabilities are defined by three acts: (1) 2002 Local Government Act; 2001 Local Electoral Act; and 2002 Local Government (Rating) Act. Local government reflects regional and local councils, and other democratically elected local bodies. The 2002 Local Government Act replaces 
the 1974 Act. The new Local Government Act, similar to the 1974 Act, provides rules under which democratically elected governments can operate. It is simpler and empowers local government, while also providing more accountability and public input. Overall, the Local Government Act requires more rigorous and transparent decision-making by local governments (Department of Internal Affairs 2005).

The Act (a) states the purpose of local government, (b) provides a framework and powers for local governments to decide which activities they undertake and the manner in which they undertake them, (c) promotes accountability of local governments to their communities, and (d) provides for local governments to play a broad role in promoting the social, economic, environmental, and cultural well-being of communities, taking a sustainable development approach. The stated purpose of local government is: (a) to enable democratic local decision-making and action by, and on behalf of, communities and (b) to promote the social, economic, environmental, and cultural well-being of communities in the present and for the future (Government of New Zealand 2004).

The Act requires local governments to facilitate a process with their communities at least every six years to identify community outcomes for the intermediate and long-term future of the district or region, with the premise that the community takes ownership of the identified outcomes. Tenyear Long Term Council Community Plans are required and must be reviewed every three years. The Long Term Council Community Plans describe the community outcomes and priorities and the activities that the local government will undertake to contribute to the outcome. "Significant activities" must be put forward in accordance with the Long Term Council Community Plans. The local authorities are charged with defining "significant activity" and how priorities are determined, both subject to public review and concordance (Government of New Zealand 2004).

\section{The Treaty of Waitangi and Natural Resource Management}

The 1841 Treaty of Waitangi, an agreement between the English Crown and the Maori, has constitutional significance that underlies the foundation of society in New Zealand. The treaty and implementation are not without controversy and differing interpretations (Orange 1987, Brookfield 1999).

The principles of the treaty are influential in the area of environmental protection and natural resource management. Under the 1987 Conservation Act, 1991 Resource Management Act, and 2002 Local Government Act, the principles of the treaty must be observed and the relationship of the Maori and their culture and traditions are considered to be a matter of national importance and must be recognized and provided for (Government of New Zealand 1987, 2004, 2005). Further, the Local Government Act is based on a quadruple bottom line (culture, social, economic, and environment) that distinguishes cultural aspects as separate from social aspects for added emphasis. The Maori believe for example, that the forest, waters, and all life supported by them, together with natural phenomenon like wind, mist, and rocks, possess mauri or life force (Barlow 1991, Llewell 2004). The primary management principal for the Maori is protection of mauri of a resource from desecration. The Maori worldview does not separate spiritual and intangible aspects from non-spiritual aspects of resource management (Tipa 2006).

Historically, a rift between treaty obligations and modern legal obligations existed. Prior to promulgation of these three Acts, New Zealand legislation did not refer to specific obligations regarding aspects of the treaty. A further breach occurred between treaty obligations and regional and local council governance, the level of government that undertakes actions that most often affect the Maori (Tunks 2002). The 1974 Local Government Act lacked treaty guarantees. This breach was rectified with inclusion of treaty provisions in the 1991 Resource Management Act and the 2002 Local Government Act. The ongoing challenge remains how to incorporate cultural aspects, including spiritual, into decision-making while also addressing the colonial and post-colonial historical legacy.

Some maintain that Maori viewpoints and values are not incorporated sufficiently into decision-making (Mutu 2002, Tunks 2002, Tipa 2006). This situation is a result of various factors including (a) lack of understanding of Maori issues 
by regional and district planners and resource consents processors, (b) limited Maori political representation and active roles in planning departments in regional and local governments, (c) lack of ability to formulate information about the Maori perspective in a manner that can be considered within the existing legal framework, (d) lack of coherent advocacy on the part of some Maori groups, and (e) limited economic resources for Maori participation (Mutu 2002, Tunks 2002, Tipa 2006). Others contend that this is also due to lack of true partnership by the "Crown" called for by the treaty and section 8 of the Resource Management Act, for example. Consultation is undertaken with the Maori as stakeholders rather than "partners" or "co-managers," or in the case of rightful "owners of water" (Tunks 2002, Turia 2006).

At the local decision-making level that is, regional and local (district or city) councils, development of practical tools are underway to help incorporate Maori cultural issues formally into decision-making on terms that local government can more readily consider. A Cultural Health Index for streams and rivers was devised. In addition, a Cultural Opportunity Matrix is under development to enable the Maori to participate in helping identify preferred flow regimes for waterways of significance (Tipa 2006, Tipa and Teirney 2006a, 2006b).

Thus a framework does exist to address Maori issues in New Zealand. A breach still exists regarding "Crown" responsibilities under the Treaty of Waitangi and the Maori role in ownership and management of water and other resources. Steps are being taken to better incorporate the Maori perspective and role in resource management.

\section{Public Consultation}

Significant public consultation and stakeholder input forms the cornerstone of existing legislation. For example, local councils are currently presenting Long Term Council Community Plans to constituents (Government of New Zealand 2004). The Long Term Council Community Plan couches investment in water infrastructure and the environment for instance, alongside other government services like libraries and footpaths. Long Term Council Community Plan feedback was completed in mid-2006 and is being incorporated into local government programs, helping set budget envelopes and allocation among various services.

Furthermore, development of regional policy statements, regional plans, and district plans involve significant public input. Generally, focus groups and public working groups are formed to participate in formulation of the statements and plans. Once draft statements or plans are published, a period exists for the public and interested parties to comment and/or protest particular aspects. Objections are reviewed and, where possible, modifications are made prior to publication of final statements or plans. Various methods are used to broach objections, including facilitated public meetings, direct negotiation, arbitration, and mediation. A last resort is referral to a special Environment Court (Somerville 2004). For issues reaching the Environment Court, final resolution may take many years.

Resource consents such as water right permits, granted under the Resource Management Act by regional and district councils, also involve public participation and review (Randerson 1997, Harris 2004, Government of New Zealand 2005). The consents can involve objections and similar facilitated dispute resolution techniques.

\section{Financing IWRM}

Financing of IWRM activities reflects a combination of resource consent user charges, general regional and local council rates, and national initiatives, which differ from region to region and local council to local council. In the Auckland Region, activities associated with IWRM are funded by rates levied by the different local councils (seven within the region) and by the Auckland Regional Council. Large rate increases have occurred in recent years to fund large infrastructure projects and differed investment. The increases have been met with significant rate payer opposition, although in the end these rates are paid. In the Otago Region, rates are supplemented by Ports of Otago revenue and therefore reduce the contributions required by rate payers.

\section{Wet Weather Quality Management in the Auckland Region}

The Auckland Region lies on the North Island 
and is defined by the political boundaries of the Auckland Regional Council. It is comprised of seven district and city councils: Rodney District, North Shore City, Auckland City, Waitakere City, Manukau City, Papakura District, and Franklin District. The Auckland Region and Auckland City in particular, is the fastest growing population center in the country. Auckland City, occupying an isthmus between the Waitemata and Manukau Harbors, accounts for 32 per cent of the region's population. Greater Auckland comprised of Auckland City together with Manukau City (24 per cent), North Shore City (16 per cent) and Waitakere City (15 per cent), totaling just over 1 million people (Auckland Regional Council et al. 2006), forms the region's principal urban center. Auckland City is the most urbanized and populous at 368,000 inhabitants (Statistics New Zealand 2002), projected to grow to 583,000 over the next 50 years (Auckland Regional Council 1999). Greater Auckland and the Auckland Region are the economic hub of the country. The Auckland Region contributed 34 per cent of the nation's gross national product, with Auckland City accounting for 50 per cent of the output in the Auckland Region (Auckland Regional Council et al. 2006). The concentration of population and urban activities pose water quality issues. The manner in which IWRM and wet weather water quality management is progressing in the Auckland region is reviewed.

The Proposed Auckland Regional Plan: Coastal was promulgated in 1999 and updated in 2004 (Auckland Regional Council 2004). The coastal plan implements the National Coastal Policy Statement by regulating activities in identified coastal management areas. The Auckland Regional Plan: Air, Land and Water was issued in 2001 and updated in 2005 (Auckland Regional Council 2005). Together, the two plans identify wet weather quality issues of concern, areas of special protection, and set forth a framework for identification of ecological and public health risks.

Inner and outer estuarine settling zones were identified; these are monitored approximately on an annual basis for a range of contaminants (Williamson and Kelly 2003). Contaminant levels of probable ecological effects were identified, although these levels are under dispute by local councils and network operators. When certain contaminant levels are exceeded, a procedure exists for further sampling to assess if adverse ecological effects are indeed occurring. The Ministry for the Environment recreational water assessment for bathing beaches (Ministry for the Environment 2003) was adopted in Variation 1 of the regional plans (Auckland Regional Council 2004, 2005). The Ministry for the Environment guideline provides a basis for public health risk assessment that incorporates sampling results, combined sewer and wastewater overflow occurrences, stormwater discharge, and public exposure. It sets a target of no more than two beach infringements per year due to poor ambient water quality.

It has been discovered that the predominant ecological contaminant of concern in the region is zinc, with the principal source being leachate from zinc-coated corrugated metal roofs located predominantly in industrial pockets (Timperley et al. 2005). Source control has been identified as the best option for stormwater quality management (Ouwejan et al. 2006). Moreover, limiting occurrences of flooding and wastewater and combined sewer overflows continue to be the focus for public health issues (Auckland City Council 2006).

While the Auckland Regional Council regional plans and Variation 1 have their basis in receiving environment issues, rules contained within Variation 1, in fact, set specific end-of-pipe discharge standards for total suspended sediment and overflow occurrences. These aspects and others, particularly contaminant levels of the regional plans, remain controversial and have been challenged. Resolution is likely many years away and is subject to an Environment Court hearing.

From a cultural perspective of wet weather water quality, the following have been identified through consultation with the Maori in the Auckland Region: (a) discharge of any liquid wastes directly to water bodies is culturally inappropriate (in first instance land treatment is acceptable); (b) different types of liquid waste such as sewage and stormwater should be kept separate and treated differently; (c) use of or maintenance of riparian zones adjacent to water bodies to control diffuse discharges or contaminants; and (d) unauthorized dumping of waste requires stronger monitoring, 
enforcement, and penalties (Auckland Regional Council 2005).

Auckland City has been at the forefront of advocating a best practicable option approach that links economic, environmental, and social tenets of sustainable water use and sustainable water resource systems consistent with the Resource Management Act. The city has taken an integrated catchment and receiving environment focus and proposed improvements for public health in highly visited bathing beach areas, flood alleviation across the city with initial focus in areas of targeted urban growth, and ecological health in inner settling zones near protected areas where there are high zinc concentration levels. Due to costs and ability to affect change, staged improvements will occur.

In Auckland City, an Integrated Catchment Study was completed that provided the city with a range of costs for improved drainage and receiving environment outcomes (Sharman et al. 2006). The city subsequently examined a range of improvement scenarios for combined and wastewater sewer overflow reduction, flood mitigation, and stormwater quality focusing on locations with the most benefits, estimating the time to achieve the improvements, and quantifying their associated costs. Through the Long Term Council Community Plan, Auckland City and its partners then consulted with the public and local Maori to determine what the drainage and environmental objectives should be, the practicality of achieving these objectives, the costs and benefits associated with them, and the effect on rates. From the scenarios and consultation, a preferred scenario was identified, equating to NZ\$2 billion of investment over the next 20 years (Auckland City Council 2006).

Based on the preferred scenario, new strategic milestones were determined in 2006. The new strategic milestones and options developed within the Integrated Catchment Study will enable the Auckland City to notify its city-wide drainage discharge network consents in 2007 (that is public filing for legal permission to operate the wastewater and stormwater networks and their associated discharges).

The approach taken by Auckland City differs somewhat from other local councils in the Auckland Region. One council for example, publicly notified a catchment based on less than one overflow event in a 5-year period. Another council performed Long Term Council Community Plan consultation in 2005, presenting impact on rates based on total suspended sediment removal per Variation 1 of the regional and coastal plans, with differences in rates based on time to achieve total suspended sediment removal. These approaches comply or exceed regulatory requirements as they currently exist in the regional plans. Also, the approaches follow end-of-pipe discharge standards. The link with public and ecological health outcomes is presumed and does not necessarily balance economic, environmental, and social policies. The challenge for the Auckland Regional Council is to achieve environmental outcomes, including water quantity and quality through a consistent and fair-handed manner while dealing with local councils and network operators that have undertaken different approaches to notify resource consents and make improvements to their drainage networks.

\section{Water Allocation in the Otago Region}

The Otago Region lies on the South Island, with its headwaters in the Southern Alps and draining to the east and south coast. It is comprised of 32,000 square kilometers, or 12 percent of New Zealand's total area. It is inhabited by 190,600 people (Statistics New Zealand 2002). Important tourist areas exist in the region largely based on natural features and the towns of Dunedin and Queenstown. Surface water is used predominantly in agriculture (83 percent), while industrial use accounts for 8 per cent and domestic use 3 percent (Lincoln Environmental 2000). Hydroelectric power generation is a significant use of water in Otago, even though much of the use is non-consumptive. Ground water accounts for 6 percent of water use, distributed evenly across the 3 consumptive use types (Lincoln Environmental 2000). Much of the region lies in the rain shadow of the Southern Alps. At the western fringe of the region adjacent to the Southern Alps, rainfall reaches $5000 \mathrm{~mm}$, while a large swath in Central Otago receives less than 400 mm (Otago Regional Council 2004a). Agricultural production in Central Otago is heavily reliant on irrigation. An example of IWRM and water allocation in the Otago Region is presented.

Water allocation and sharing in the Otago Region are governed by the Regional Plan: Water and 
Plan Change 1A, together referred to as the Water Plan (Otago Regional Council 2004b, 2006b), and developed under the provisions of the Resource Management Act. Water allocation is based on issuance of resource consents, water user group participation, river flow monitoring, and setting minimum environmental flows. Individuals hold resource consents to divert water. Water users hold primary or supplementary consents, with allocation limits set in the Water Plan for many streams.

Minimum environmental flows are assessed though a variety of methods in New Zealand, including RHYHABSIM, a local adaptation of PHABSIM (Jowett 1996) and the Instream Flow Incremental Methodology (Bovee 1982). The Water Plan stipulates that water diversions cannot infringe upon pre-determined minimum environmental flows. When flow reaches a set low level, notice is given and supplementary diversions are suspended. Diversion rostering commences to avoid flow reaching the minimum environmental flow. River flows are monitored by the Otago Regional Council. Water Allocation Committees have been set up by the Otago Regional Council to apply water diversion rosters based on existing resource consents granted by the Council (Otago Regional Council 2004b, 2006b). Extensive community consultation is undertaken to ensure that the system is well understood.

In one catchment, an Environment Court decision affecting the Water Plan determined that if the minimum environmental flow was breached, primary consents would cease operation. The flow must then recover to a "bounce" back level, above the minimum environmental flow, before primary consents can resume operation. This bounce back provision was intended to provide added incentive to avoid minimum environmental flow breach. Human and stock water consumption requirements however, lie outside of these rules and may continue (Otago Regional Council 2004b, 2006b).

Further, the Water Plan recognizes existing "mining water rights" unique to the Otago Region, which date back to the gold rush days of the $19^{\text {th }}$ century. After cessation of mining, canals and diversion rights were used for irrigation. These rights expire in 2021 and will then come under Resource Management Act regulation. Rivers affected by mining rights do not require environmental flows, and are the reason why many rivers can be severely "over allocated" on paper. Any maintenance of environmental flows would have to be on a voluntary basis until 2021 and therefore can seriously compromise the ability of the Otago Regional Council to manage water sustainably in the meantime (Deans 2004b).

Where rivers are over-allocated a "sinking lid" approach to primary allocation is applied. If any consents are surrendered, lapse, cancelled, or are not replaced on expiration, they lose their primary allocation status. The allocation previously provided to those consents will not be reallocated (Otago Regional Council 2004b).

The transition of the Otago Region's mining rights to consents requires collaborative thinking involving all stakeholders to achieve an acceptable community-driven water management strategy. This is a current major initiative by the Otago Regional Council where local fora are being held as part of the Water Plan change public submission process (Otago Regional Council 2006a).

\section{Discussion and Conclusions}

Strong enabling legislation exists in New Zealand based solidly on sustainable development criteria, with regional gerraovernment jurisdiction based on catchments. Significant public consultation is undertaken and active local participation and decision-making is commonplace. The local emphasis allows plans to strongly reflect local issues and can provide for added local accountability.

However, lack of central government involvement in strategic guidance, in particular lack of national policy statements has led in part to each region producing different water sharing and water quality regulations. In some instances significant differences exist within small areal extent and similar conditions, a situation that could be interpreted as too diverse or decentralized. In addition, each region and council expends effort to devise their own rules about common aspects across the country for their regional statements and plans. These issues will become more pronounced in time as New Zealand faces a range of water quality and quantity issues.

One challenge confronting New Zealand is the need to address significant non-point source contamination from urban, agricultural, and animal 
husbandry practices, management of which is just commencing in earnest in parts of the country. New Zealand faces the challenge of restoring water quality and degraded river and estuarine habitats in locations of intense human use such as Greater Auckland, central North Island, Canterbury Plains and the Otago Region, while also protecting relatively pristine areas that include the west coast of the South Island. Public and private participation is required to adequately address this challenge. For example, a promising private initiative is being led by Fonterra, a dairy co-operative group representing most dairies in New Zealand, as part of the "Clean Streams" initiative. The cooperative has taken a proactive role, collaborating with dairy producers, local government, Ministry for the Environment, Ministry of Agriculture and Forestry, and researchers to reduce contamination emanating from dairies (Fonterra Co-operative Group et al. 2003).

Another challenge in particular areas is water allocation. Central government has proposed investigating further using water consent transfers to improve water use (Ministry for the Environment 2006). Concepts like water markets, however, have been met with stiff vocal opposition in some circles (Turia 2006). Others are addressing how to incorporate environmental flows into rivers with existing over-allocation of water (Otago Regional Council 2006a).

Yet another challenge is to streamline provision of government services. In Auckland City, seven borough councils were amalgamated into one city in 1989, while seven district/city councils still exist in the Auckland Region. Currently, eight entities provide water supply, wastewater and stormwater services to Greater Auckland with a population of 1.2 million. Since 2000, discussion exists to amalgamate water services to provide economies of scale and efficiencies (Auckland Water Review 2001).

Several of these issues are recognized by central government. Government reform and amalgamation are tied up with politics, which is currently highly contentious due to the coalition of the controlling party with minority parties to form a viable government. Action is therefore unlikely in the near term. On the other hand, review by central government in conjunction with local government is currently underway to provide national guidance to better address water allocation and sustainable water practices as part of the "Sustainable Water Program of Action." A series of policy statements are expected from the first half of 2007, initially addressing water allocation. As stated at the outset of this section, strong enabling legislation based on sustainability concepts and governance based on catchments already exist, providing a solid framework for IWRM. Publication of national water policy statements and resulting follow up actions at the local government level will determine how much further IWRM is put into practice, based on tenets of sustainable water use and sustainable water resource systems in New Zealand.

\section{Author Bios and Contact Information}

MATTHEW DAVIs is a senior water resource engineer with CAL Engineering Management of Auckland City, New Zealand. From 2001-2005, he was the technical manager of the NZ\$23.5 million Integrated Catchment Study of Auckland City. Previously he worked in California and Chile on water management and environmental impact assessments. He has an M.S. in civil and environmental engineering and is currently completing a Ph.D. on integrated water resource management and water sharing in Chile at the University of California, Davis. $\mathrm{He}$ can be contacted at CAL Engineering Management, 73 Almorah Road, Epsom, Auckland City, New Zealand, mddavis67nz@yahoo.co.nz and WAI Institute c/o 801 Malaga Ave., Davis, California 95616-0146, matthew. davis@waiinstitute.org.

John Threlfall has a Ph.D. in fluvial geomorphology from Southampton University and is the Director of Environmental Information and Science for the Otago Regional Council, New Zealand. Responsibility in this role includes co-ordinating and interpreting scientific investigations of water resources in the large, diverse and often water short Otago region. Previously, he worked for environmental engineering consultancies in both the United Kingdom and New Zealand and the environmental regulator in the United Kingdom. He also worked in water research and has been a technical specialist in overseas projects. He can be contacted at Otago Regional Council, Private Bag 1954, Dunedin, New Zealand. john.threlfall@orc.govt.nz.

\section{References}

American Society of Civil Engineers and United Nations Educational, Scientific, and Cultural Organization. 
1998. Sustainability Criteria for Water Resources Systems. American Society of Civil Engineers, Reston, Virginia.

Auckland City Council. 2006. Auckland City's Longterm Plan 2006-2016. Auckland City Council, Auckland City, New Zealand.

Auckland Regional Council and Local Councils. 2006. Business and Economy. The Auckland Region. '06. Auckland Regional Council, Auckland City, New Zealand.

Auckland Regional Council. 1999. Growth: The 50Year Challenge. Regional Growth Forum Summary. Auckland Regional Council, Auckland City, New Zealand.

Auckland Regional Council. 2004. Auckland Regional Plan: Coastal (Operative). Incorporating Variation 1 (Notified 21 June 2002). Auckland Regional Council, Auckland City, New Zealand.

Auckland Regional Council. 2005. Auckland Regional Plan: Air, Land and Water. (Notified 23 October 2001). Incorporating Variation 1 (Notified 21 June 2002). Highlighted to Indicate Provisions Appealed (June 2005). Auckland Regional Council, Auckland City, New Zealand.

Auckland Water Review. 2001. Review Update June 2001. Auckland Water Review, Auckland City, New Zealand. Online at <http:/www. aucklandwaterreview.co.nz $>$. Accessed 1 January 2002.

Barlow, C. 1991. Tikanga Whakaaro: Key Concepts in Maori Culture. Oxford University Press, Auckland City, New Zealand.

Berry, S. and I. Cowper. 1997. Water law. Chapter 7 In Environmental \& Resource Management Law. Butterworths, Wellington, New Zealand.

Biswas, A. K. 2004. Integrated water resources management: A reassessment. Water International 29(2): 248-256.

Bovee, K. D. 1982. A Guide to Stream Habitat Analysis Using the Instream Flow Incremental Methodology. United States Fish and Wildlife Service Biological Services Program FWS/OBS-82/26, Instream Flow Information Paper 12. United States Government Printing Office, Washington D.C.

Brookfield, F. M. 1999. Waitangi and Indigenous Rights: Revolution, Law \& Legitimation. Auckland University Press, Auckland City, New Zealand.

Burton, L. and C. Cocklin. 1996. Water resource management and environmental policy reform in New
Zealand: Regionalism, allocation, and indigenous relations. Part I. Colorado Journal of International Environmental Law and Policy 7(1): 75-106.

Deans, N. 2004a. Freshwater values: Duties and responsibilities under the RMA. Chapter 7A In Harris, R. (Ed.). Handbook of Environmental Law. Royal Forest and Bird Protection Society, Wellington, New Zealand.

Deans, N. 2004b. Issues relating to water and mechanisms for protecting water-related values. Chapter 7B In Harris, R. (Ed.). Handbook of Environmental Law. Royal Forest and Bird Protection Society, Wellington, New Zealand.

Department of Internal Affairs. 2005. Strategy for Evaluating Local Government Legislation. Department of Internal Affairs, Wellington, New Zealand.

Fonterra Co-operative Group, Local Government New Zealand, Ministry for the Environment, and Ministry of Agriculture and Forestry. 2003. Dairying and Clean Streams Accord. Fonterra, Ministry for the Environment, and Ministry of Agriculture and Forestry, Wellington, New Zealand.

Gleick, P., P. Loh, S. Gomez, and J. Morrison. 1995. California Water 2020: A Sustainable Vision. Pacific Institute for Studies in Development, Environment, and Security, Oakland, California.

Government of New Zealand. 1987. Conservation Act 1987. Government of New Zealand, Wellington, New Zealand.

Government of New Zealand. 2004. Local Government Act 2002. Government of New Zealand, Wellington, New Zealand.

Government of New Zealand. 2005. Resource Management Act 1991 (including Amendment Acts through 2005). Government of New Zealand, Wellington, New Zealand.

Guerquin, F., T. Ahmed, M. Hua, T. Ikeda, V. Ozbilen, and M. Schuttelaar. 2003. World Water Actions: Making Water Flow for All. World Water Council, Marseille, France.

Harris, R. (Ed.) 2004. Handbook of Environmental Law. Royal Forest and Bird Protection Society, Wellington, New Zealand.

Jowett, I. 1996. RHYHABSIM: River Hydraulics and Habitat Simulation Computer Model. National Institute for Water and Atmospheric Research, Hamilton, New Zealand.

Kirkpatrick, R. 1999. Bateman Contemporary Atlas 
New Zealand: The Shapes of Our Nation. David Bateman Ltd, Auckland City, New Zealand.

Lee, T. R. 1999. Water Management in the 21st Century: The Allocation Imperative. Edward Elgar Publishing Incoporated: Northampton, Massachussetts.

Lincoln Environment. 2000. Information on Water Alloction in New Zealand. Report 4375/1. Ministry for the Environment, Wellington, New Zealand.

Llewell, D. 2004. Maori and the environment. Chapter 19 In Handbook of Environmental Law. Royal Forest and Bird Protection Society, Wellington, New Zealand.

Ministry for the Environment. 2001. The Resource Management Act and You: Getting in on the Act. Ministry for the Environment, Wellington, New Zealand.

Ministry for the Environment. 2003. Microbiological Water Quality Guidelines for Marine and Freshwater Recreational Areas. Ministry for the Environment, Wellington, New Zealand.

Ministry for the Environment. 2004. Freshwater for a Sustainable Future: Issues and Options. Ministry for the Environment, Wellington, New Zealand.

Ministry for the Environment. 2006. Freshwater for the Future: A Supporting Document. Ministry for the Environment, Wellington, New Zealand.

Mitchell, B. (Ed.). 1990. Integrated Water Management: International Experiences and Perspectives. Bellhaven Press, New York.

Molle, F. 2003. Development Trajectories of River Basins: A Conceptual Framework. Research Report 72. International Water Management Institute, Colombo, Sri Lanka.

Mutu, M. 2002. Barriers to Tangata Whenua participation in resource management. Chapter 5 In Kwharu M. (Ed.). Whenua: Managing our Resources. Reed Publishing, Auckland City, New Zealand.

Newson, M. 1997. Land, Water and Development. Routledge, New York.

Orange, C. 1987. The Treaty of Waitangi. Bridget Williams Book Limited, Wellington, New Zealand.

Otago Regional Council 2004a. GrowOTAGO, Climate and Soil Data. Online at http://www.orc.govt.nz.

Otago Regional Council. 2004b. Regional Plan: Water for Otago. Otago Regional Council, Dunedin, New Zealand.

Otago Regional Council. 2006a. Water users reach consensus at forum. News Brief 23 August 2006.
Otago Regional Council, Dunedin, New Zealand.

Otago Regional Council. 2006b. Plan Change 1A to the Regional Plan: Water for Otago. Otago Regional Council, Dunedin, New Zealand.

Ouwejan, R., R. Seyb, M. Davis, I. Mayhew, G. Paterson, P. Kinley, and B. Sharman. 2006. Source control or traditional BMPs? An assessment of benefits and costs in Auckland City. Stormwater 2006. New Zealand Water and Wastes Association, Wellington, New Zealand.

Randerson, T. 1997. Resource Management Act 1991. Chapter 3 In Williams D. A. R. (Ed.). Environmental \& Resource Management Law, Butterworths, Wellington, New Zealand.

Sharman, B., G. Paterson, R. Brown, M. D. Davis, P. Kinley, and S. Ranchhod. 2006. The integrated catchment study of Auckland City (New Zealand): Overview. World Water and Environmental Resources Congress 2006. American Society of Civil Engineers, Reston, Virginia.

Somerville, R. 2004. Additional dispute resolution. Chapter 5 In Harris R. (Ed.). Handbook of Environmental Law. Royal Forest and Bird Protection Society, Wellington, New Zealand.

Statistics New Zealand. 2002. Census 2001. Statistics New Zealand, Wellington, New Zealand.

Timperley, M., B. Williamson, G. Mills, B. Horne, and M. Qaumrul Hasan. 2005. Sources of Loads of Metals in Urban Stormwater. NIWA Client Report AKL2004070 and Auckland Regional Council Technical Publication ARC04104. Auckland Regional Council and National Institute for Water and Atmospheric Research, Auckland City, New Zealand.

Tipa, G. 2006. Incorporating a cultural perspective in freshwater management. Water 2006. 1-4 August, Auckland City. Events Division Limited, Wellington, New Zealand.

Tipa, G. and L. Teirney 2006a. A Cultural Health Index for Streams and Waterways: A Tool for Nationwide Use. Ministry for the Environment, Wellington, New Zealand.

Tipa, G. and L. Teirney 2006b. Using the Cultural Health Index: How to Assess the Health of Streams and Waterways. Ministry for the Environment, Wellington, New Zealand.

Tunks, A. 2002. Rangatiratanga, partnership and protection. Chapter 16 In Kwharu, M. (Ed.). Whenua: Managing our Resources. Reed Publishing, Auckland City, New Zealand.

Turia, T. 2006. Returning to our rivers. The NZWWA 
Journal. Water \& Wastes in New Zealand 145: 2527.

Ward, A. 1999. An Unsettled History: Treaty claims in New Zealand. Bridget Williams Books: Wellington, New Zealand.

White, G. F. 1998. Reflections on the 50-year international search for integrated water management. Water Policy 1(1): 21-27.

Williamson, B. and S. Kelley. 2003. Regional Discharges Project. Marine Receiving Environment Status Report 2003. Technical Publication 2003. Auckland Regional Council, Auckland City, New Zealand. 